\section{Carl-Henrik Nordström}

\section{Comment on "Changes in cerebral interstitial glycerol concentration in head injured patients; correlation with secondary events"}

Received: 21 July 2003

Accepted: 12 November 2003

Published online: 6 December 2003

(C) Springer-Verlag 2003

Sir: I read with interest the report by Peerdeman et al. (Changes in cerebral interstitial glycerol concentration in head-injured patient; correlation with secondary events) published on-line 20 June 2003 [1]

From a series of 14 patients with severe traumatic brain injury Peerdeman et al. [1] conclude that (1) "measuring interstitial glycerol for early detection of secondary adverse events, which possibly lead to secondary brain damage, does not seem useful" and (2) "a peak level of interstitial glycerol above $150 \mu \mathrm{mol} / \mathrm{l}$ has a positive predictive value of $100 \%$ for unfavourable outcome". Both conclusions may be questioned.

In their study Peerdeman et al. intended to insert the microdialysis catheter into relatively "normal" brain tissue and, accordingly, the biochemical pattern would be expected to be close to normal $[2,3,4]$. The authors then related interstitial glycerol level to what they regarded as significant adverse secondary events: (1) sustained (>30 min) CPP below $70 \mathrm{mmHg}$, (2) sustained ICP (>30 $\mathrm{min}$ ) above $25 \mathrm{mmHg}$, (3) $\mathrm{PaCO}_{2}$ below $30 \mathrm{mmHg}$, (4) $\mathrm{SaO}_{2}$ below
$95 \%$ and (5) sustained (60 min) temperature above $38^{\circ} \mathrm{C}$. However, there is no reason to assume that these limits should be critical for perturbation of energy metabolism and degradation of cellular membranes in "normal" brain tissue. It has recently been shown that, in patients with severe traumatic brain lesions, a decrease in CPP to $50-60 \mathrm{mmHg}$ is usually not associated with any indications of secondary metabolic perturbation (not even in the penumbra zone surrounding an evacuated focal mass lesion) [5].

Conclusion 2 may, by chance, be true for this small material but as a general statement it is obviously erroneous. Firstly, in a study of 48 patients with severe traumatic brain lesions the mean glycerol level was $334 \mu \mathrm{mol} / \mathrm{l}$ in the penumbra zone during the first $12 \mathrm{~h}$ after the start of treatment [4]. Most of these patients had a favourable outcome. Secondly, during wakefulness the interstitial glycerol level was $82 \pm 44 \mu \mathrm{mol} / 1$ (mean \pm S.D.) in normal human brain [2], which implies that $16 \%$ of the values were above $126 \mu \mathrm{mol} / \mathrm{l}$ and $2.5 \%$ above $170 \mu \mathrm{mol} / \mathrm{l}$. Thirdly, like other local techniques, microdialysis only gives information regarding tissue biochemistry in a zone closely surrounding the probe. The biochemical data will give information regarding "tissue outcome" in this zone but extrapolating data from regional metabolism to predict "clinical outcome" is obviously unwarranted. Microdialysis with bedside analysis of cerebral energy metabolism is of direct therapeutic importance only when integrated in the total clinical, physiological and pharmacological evaluation.

The case illustrated in the report initially showed a high glycerol level, which started to increase (to $>600 \mu \mathrm{mol} / \mathrm{l}$ ) about $6 \mathrm{~h}$ before the increase in ICP. In the absence of information regarding other biochemical variables, this increase may well represent an "early warning" of deterioration. The later slow, continuous decrease in glycerol during the increase in ICP may indicate either that the tissue has temporarily recovered or that no viable cells surround the microdialysis catheter and no further degradation of cell membranes will take place.

\section{References}

1. Peerdeman SM, Girbes ARJ, Polderman KH, Vandertorp WP (2003) Changes in cerebral interstitial glycerol concentration in head-injured patients; correlation with secondary events. Intensive Care Med (http://dx.doi.org/10.1007/s00134003-1850-8)

2. Reinstrup P, Ståhl N, Hallström Å, Mellergård $\mathrm{P}$, Uski $\mathrm{T}$, Ungerstedt $\mathrm{U}$, Nordström CH (2000) Intracerebral microdialysis in clinical practice. Normal values and variations during anaesthesia and neurosurgical operations. Neurosurgery 47:701-710

3. Ståhl N, Mellergård P, Hallström Ungerstedt U, Nordström CH (2001) Intracerebral microdialysis and bedside biochemical analysis in patients with fatal traumatic brain lesions. Acta Anaesthesiol Scand 45:977-985

4. Ståhl N, Ungerstedt U, Nordström CH (2001) Brain energy metabolism during controlled reduction of cerebral perfusion pressure in severe head injuries. Intensive Care Med 27:1215-1223

5. Nordström $\mathrm{CH}$, Reinstrup $\mathrm{P}, \mathrm{Xu} \mathrm{W}$, Gärdenfors A, Ungerstedt U (2003) Assessment of the lower limit for cerebral perfusion pressure in severe head injuries by bedside monitoring of regional energy metabolism. Anesthesiology 98:809-814

\section{C.-H. Nordström (ه)}

Department of Neuroscience, Lund University Hospital,

22185 Lund, Sweden

e-mail: carl-henrik.nordstrom@neurokir.lu.se 